\title{
静水面上に連続流出する油層の拡がりに関する研究
}

\section{A STUDY OF THE SPREAD OF CONTINUOUSLY SPILLED OIL ON CALM WATER}

\author{
埜口英昭* ·平野宗夫** \\ By Hideaki NOGUCHI and Muneo HIRANO
}

\begin{abstract}
In this study, a mathematical model of axisymmetrical oil spread on calm water is developed. Two basic equations are used to express the characteristics of oil slick : one is the conservation of volume and the other is the $r$-component of the equation of motion. By using the kinematic wave theory, those equations are transformed into characteristic equations along the characteristic curve. These simultaneous equations are solved to give the spreading rate of the oil front. This model describes the motion of the oil slick ranging from the gravity-inertial to the gravity-viscous spread. The theory is examined by comparing it with the experiments for the spread of continuously spilled oil from a small outlet onto open calm water.

Keywords : oil spill, spreading of oil on water, kinematic wave theory
\end{abstract}

\section{1. まえがき}

油濁による海洋污染の大きな原因の 1 つとして, 航行 船舶や石油貯蔵施設の事故による大量の油の流出があ る. 過去にも三菱石油水島製油所事故 ${ }^{1)}$ (1974 年 12 年 18 日, 水島), アコモ・カジス号事故 ${ }^{2)}$ (1978 年 3 月 16 日, フランス, ブルタニュー沖）などの大量の石油の流 出事故が発生し, そのたびに生態系や水産業は大きな打 撃を受けた。近年は，このような大規模な油流出事故は 発生しておらず，また環境庁水質保全局の資料 ${ }^{3)}$ にる と, 海洋污染防止関連の法律の整備, 監視体制の強化等 により，1975 年以降の船舶等からの油による海洋污染 確認件数は，かなり減少傾向にある.それでも 1986 年 度の環境白書 ${ }^{4}$ の報告によると, 1985 年のわが国におけ る海洋污染発生確認件数のうち, 油による污染は 628 件 と, 全体の $78 \%$ を占めており，このうち船舶からのも のが 475 件と大半を占める状況にある.

最近の世界の経済情勢は, 2 度にわたる石油危機を経 て停滞気味であり, 1980 年頃から世界の原油生産量は

* 正会員 中国工業技術試験所 海洋開発部 （开737-01 吳市広末広 2-2-2）

** 正会員 工博 九州大学教授 工学部水工土木工学科 ( ₹812 福岡市東区箱崎 6-1-10)
减少傾向にある5). わが国における石油消費量をみても， 産業における省エネルギー・燃料転換の急速な進展等に より 1975 年度以降大幅な減少を続け, ここ数年は横ば いの状態が続いている ${ }^{6)}$ ．また，将来における石油資源 の枯渇というような，長期的な視点でみた場合の石油需 給逼迫という状況に対しては，代替えエネルギ一の開発 研究も進められつつある. しかし，1990 年代以降も当 分の間は, 必要とするエネルギーの大部分は石油に頼ら ざるを得ず，わが国のエネルギー政策の一環としての， 大型タンカーによる石油洋上備蓄や, むつ小河原, 上五 島などの国家石油備蓄基地建設計画の実施も，そのよう な長期展望に基づくものと考えられる.

このような現状を考慮すると, 今後とも石油の大量流 出事故の潜在的な危険性は常に存在しているのであり, 十分な防災体制を整備して，流出事故を未然に防止する 日常的な努力を㤐ってはならないが，不幸にして事故が 発生し大量の油が流出したとき, 污染地域を予測し, そ の処理作業を効果的に進めるためにも，油の拡がりを予 测する手法の確立が必要である。本研究は，このような 大量流出油の流動現象の基本的な特性を明らかにし，そ の拡がりを予測する手法を見出すための一環として行っ たものである.

広い海上に一時に大量の油が流出した場合, 油層の拡 
がり特性を決めるのに重要な役割を果たす物理因子は, 油層と周囲水の間で作用する重力, 慣性力, 粘性力等で ある．実際の海上では，これらの作用に，潮流，風，波 等の作用が重なって, その拡がりが決定される7n.この うち, 重力, 慣性力等の基本的因子の作用が支配的な静 水面上の拡がりについては, $\mathrm{Fay}^{8)}$ の提出したモデルが 代表的なものであろう. Fay は, 静水面上に流出した 油について，時間の経過とともにいずれの力が卓越する かを分析し，その拡がりが（I）重力・慣性力領域，（II） 重力・粘性力領域, ( III) 表面張力・粘性力領域の 3 つ の領域に分類できることを示した。

Hoult $^{9)}$, Fannelop \& Waldman ${ }^{10), 11)}$, Buckmaster ${ }^{12)}$ らは, Fay のモデルを発展させ, 相似解を仮定して油 の運動方程式を理論的に解くことを試みたが，結果的に はF Fay のモデルによる結論の域を出ていないようであ る。また, $\mathrm{Abbott}^{13)}$ のように, 重力・慣性力領域での 拡がりを特性曲線法によって数値的に解いた例もある が，実際の現象への適用範囲はかなり限定されると考え られる.なお，ここに挙げた研究例は，いずれも，水面 上に拘束されて静止していた一定量の油が，ある瞬間に 解き放たれて拡がる，いわゆる瞬間流出の形態について 取り扱ったもので，水面に油が連続的に流出して拡がる 連続流出の場合についての研究は，その例をみないよう である。

貯水池における turbidity current のように，周囲流体 より重い流体が重力の作用で底面に沿って流動する，い わゆる傾斜密度流の先端部の流動は, 周囲水の連行とい う点を除けば，水面上を拡がる油層先端部の流動に類似 した非定常性の強い現象亡考えられる。このような密度 流先端部の流動機構の解明を目的とした研究は多いが, 最近では平野・羽田野 ${ }^{14), 15}$ の研究がある。平野らは，密 度流先端部の運動を非定常な二層密度流として扱い，特 性曲線法により先端速度および濃度の流下方向の変化を 規定する式を導いた。

本研究は，平野らと同様の解析法を油層の拡がりに適 用して, 静水面上に流出した油層の拡がりを運動方程式 および連続の式を用いて表わすとともに，特性微分方程 式を作ってこれを解き，油層先端の速度と油層の拡がり 半径の関係を表わす式を求めた。さらに，それを連続流 出での実験結果と比較して, 式中に含まれるパラメー 夕一を決定した。なお，この手法は，油の拡がりを Fay のモデルのように時間的な領域区分することなく 一貫して記述できるという点で一歩前進した解法といえ よう.

\section{2. 油層の拡がりの解析法}

（1） 解析のモデル
広い静水面上に大量の油が流出して拡がっている状態 について考える．このとき流出した油層を拡げる力とし て作用するのは重力で, 油が水より軽いため, 油層の重 心が浮力の中心より高くなり，その結果生じる圧力勾配 によって，外側へ拡がろうとする力である．油層が薄層 になると, 表面張力が油層を拡げる力として卓越してく ると考えられるが，ここでは表面張力の作用は考慮しな いものとする．このような油層を拡げようとする力に対 し，抵抗として作用するのは，油層の運動によって生じ る周囲水の慣性抵抗と, 油水界面での界面抵抗である.

Fig. 1 に示すように，流出した油は同心円状に四方に急 速に拡がっており，これを水平方向に $r$ 軸，鉛直方向 に $z$ 軸をもつ軸対称の拡がりとしてモデル化する. $r$ 軸方向の油の流速を $u, z$ 軸方向の油の流速を $w$ とする と, 油の拡がりを表わす連続の式， $r$ 軸方向の運動方 程式，および $z$ 軸方向の運動方程式は，それぞれ次の ように表わされる.

$$
\begin{aligned}
& \frac{\partial u}{\partial r}+\frac{\partial w}{\partial z}+\frac{u}{r}=0 \\
& \frac{\partial u}{\partial t}+u \frac{\partial u}{\partial r}+w \frac{\partial u}{\partial z}=-\frac{1}{\rho_{0}} \frac{\partial p}{\partial r}+\frac{\mu_{0}}{\rho_{0}} \frac{\partial^{2} u}{\partial z^{2}} \\
& \frac{\partial w}{\partial t}+u \frac{\partial w}{\partial r}+w \frac{\partial w}{\partial z}=-g-\frac{1}{\rho_{0}} \frac{\partial p}{\partial z}
\end{aligned}
$$

ここに, $\rho_{0}$ は油の密度, $p$ は油層内の圧力, $\mu_{0}$ は油の 粘性係数, $g$ は重力の加速度である.

Fig. 1 に示すように, 油層表面の高さを $z_{e}$, 油水界面 の高さを $z_{i}$ で表わすと，それぞれの位置において $z$ 軸 方向の流速 $w$ は, 次のように表わされる.

$$
\begin{aligned}
& w\left(z_{e}\right)=\frac{\partial z_{e}}{\partial t}+u\left(z_{e}\right) \frac{\partial z_{e}}{\partial r} . \\
& w\left(z_{i}\right)=\frac{\partial z_{i}}{\partial t}+u\left(z_{i}\right) \frac{\partial z_{i}}{\partial r} .
\end{aligned}
$$

式（3）において, 油層の鉛直方向の慣性項は小さい と仮定して無視すると，静水圧分布の仮定，

$$
p(z)=\rho_{0} g\left(z_{e}-z\right)
$$

が導かれる.

また, $z_{e}$ と $\delta$ の間には次式の関係が成り立つ.

$z_{e}=\delta \frac{\Delta \rho}{\rho_{w}}$

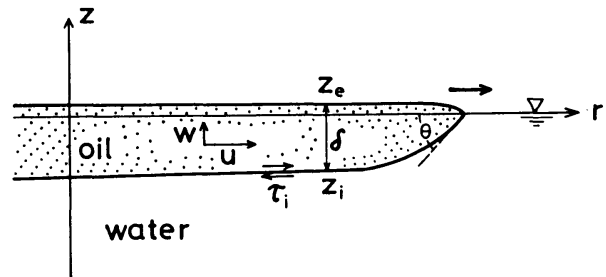

Fig. 1 Schematic sketch of oil slick 
ここに, $\rho_{w}$ は水の密度, $\Delta \rho=\rho_{w}-\rho_{0}$ である.

油層内での $r$ 軸方向断面平均流速を $U$, 油層の厚さ を $\delta$ で表わし, 式 (1), (2) を $z_{i}$ から $z_{e}$ まで積分し て, 式 (4),（5)，(6) および（7）の関係を用いて 若干の計算を行うと, 油層の運動を表わす基礎方程式と して,

・連続の式：

$\frac{\partial \delta}{\partial t}+U \frac{\partial \delta}{\partial r}+\delta\left(\frac{\partial U}{\partial r}+\frac{U}{r}\right)=0$

- $r$ 軸方向の運動方程式：

$$
\frac{\partial U}{\partial t}+U \frac{\partial U}{\partial r}=-g \frac{\Delta \rho}{\rho_{w}} \frac{\partial \delta}{\partial r}-\frac{\tau_{i}}{\delta \rho_{0}}
$$

が得られる.ここに， $\tau_{i}$ は油水界面でのせん断応力で, $\tau_{i} \equiv \mu_{0}(\partial u / \partial z)_{z \iota}$ である.

なお，ここでは前述のように表面張力は考虑されてい ないので, 油層が薄層になり, 表面張力が油を拡げる力 として卓越する領域では, 以下に述べる解析法は適用で きない，また，流出する油層は均質で，二ュートン流体 として扱うことができ, 蒸発, 溶解による体積减および 物性の変化はないものとする。

（2）特性微分方程式による解法

一階偏微分方程式の特性帯の理論 ${ }^{16)}$ によると, 式 ( 8) および（9）に対する特性微分方程式は，それぞれ次式 の形に表わされる.

$$
\begin{aligned}
& \frac{d t}{1}=\frac{d r}{U}=-\frac{d \delta}{\delta\left(\frac{\partial U}{\partial r}+\frac{U}{r}\right)} \cdots \\
& \frac{d t}{1}=\frac{d r}{U}=-\frac{d U}{g \frac{\Delta \rho}{\rho_{w}} \frac{\partial \delta}{\partial r}+\frac{\tau_{i}}{\delta \rho_{0}}}
\end{aligned}
$$

式 (10), (11) から, 油層の任意断面での厚さ $\delta$ および 平均流速 $U$ は, 特性曲線 $d r / d t=U$ 上で, それぞれ

$$
\begin{aligned}
& \frac{d \delta}{d r}=-\delta\left(\frac{1}{U} \frac{\partial U}{\partial r}+\frac{1}{r}\right) \cdots \cdots \\
& \frac{d U^{2}}{d r}=-2\left(g \frac{\Delta \rho}{\rho_{w}} \frac{\partial \delta}{\partial r}+\frac{\tau_{i}}{\delta \rho_{0}}\right)
\end{aligned}
$$

の形に表わされる. 式 (12), (13) を連立で解くと, 特 性曲線に沿った $\delta$ および $U$ の変化を求めることができ るが，両式には偏微分項 $\partial U / \partial r$ および $\partial \delta / \partial r$ が含ま れるため，一般に解くことが困難である。そこで，ここ では油層先端部付近の流速および油層厚さに，次のよう な相似性の仮定,

$$
\frac{U}{U_{s}}=\zeta\left(\frac{r}{r_{f}}\right), \frac{\delta}{\delta_{f}}=\psi\left(\frac{r}{r_{s}}\right)
$$

を導入して解析を進める.ここに, 添字 $f$ は油層先端 部 $\left(r=r_{s}\right)$ での $U$ および $\delta$ の値を, $\zeta\left(r / r_{s}\right)$ および $\psi\left(r / r_{s}\right)$ は $r / r_{f}$ についての関数を表わす. 式 (14) を $r$ で微分すると，

$$
\left.\begin{array}{l}
\frac{\partial U}{\partial r}=\frac{U_{f}}{r_{f}} \zeta^{\prime}\left(\frac{r}{r_{f}}\right) \\
\frac{\partial \delta}{\partial r}=\frac{\delta_{f}}{r_{f}} \psi^{\prime}\left(\frac{r}{r_{f}}\right)
\end{array}\right\}
$$

となり，r=rs のところでは，

$$
\begin{aligned}
& {\left[\frac{\partial U}{\partial r}\right]_{f}=\frac{U_{f}}{r_{f}} \zeta^{\prime}(1)} \\
& {\left[\frac{\partial \delta}{\partial r}\right]_{f}=\frac{\delta_{f}}{r_{f}} \psi^{\prime}(1) \cdots}
\end{aligned}
$$

と表わされる.

式（12）を油層先端部に適用し式（16）を考慮すると,

$$
\frac{d \delta_{f}}{d r_{f}}=-\left(C_{1}+1\right) \frac{\delta_{f}}{r_{f}}
$$

が得られる.ここに， $C_{1}=\zeta^{\prime}(1)$ である. 式（18）は容 易に積分できて次式の解が得られる.

$$
\frac{\delta_{f}}{\delta_{s}}=\left(\frac{r_{f}}{r_{s}}\right)^{-\left(c_{1}+1\right)} .
$$

ここに， $\delta_{s}$ は初期条件 $r_{f}=r_{s}$ の位置での油層の厚さを 表わす。

次に, 式 (13) を油層先端部に適用し, 式中で油層底 面に働く抵抗力 $\tau_{i}$ を,

$$
\frac{\tau_{i}}{\rho_{0}}=\frac{1}{2} f_{i} U_{f}^{2}
$$

と置く. $f_{i}$ は抵抗係数である. 式 (17) および (19) を用いて式（13）を変形すると，

$$
\frac{d U_{f}^{2}}{d r_{f}}+\frac{f_{i}}{\delta_{s}}\left(\frac{r_{f}}{r_{s}}\right)^{c_{1}+1} U_{f}^{2}+2 g^{\prime} C_{2}\left(\frac{\delta_{s}}{r_{s}}\right)\left(\frac{r_{f}}{r_{s}}\right)^{-\left(c_{1}+2\right)}=0
$$

となる，ここに， $C_{2}=\psi^{\prime}(1), g^{\prime}=g\left(\Delta \rho / \rho_{w}\right)$ である.

$f_{i}$ を定数と仮定し, 初期条件として, $r_{f}=r_{s}$ の点で の油の流速を $U_{f}=U_{s}$, 油層の厚さを $\delta_{f}=\delta_{s}$ とし, さら に, $r_{s} / r_{s}=r_{*}$, および $U_{f} / U_{s}=U_{n}$ と置いて常微分方 程式 (21) を解くと, 油層先端部の無次元速度 $U_{n}$ は,

$$
\begin{aligned}
U_{n}^{2}= & \exp \left\{K\left(1-r_{*}^{c_{1}+2}\right)\right\}-\frac{2 C_{2}}{F_{r s}^{2}} \exp \left\{-K \cdot r_{*}^{c_{1}+2}\right\} \\
& \times \int_{1}^{r_{*}} u^{-\left(c_{1}+2\right)} \cdot \exp \left\{K \cdot u^{c_{1}+2}\right\} d u \cdots \cdots \cdots \cdots \cdots
\end{aligned}
$$

で表わされる.ここに,

$$
\begin{gathered}
K=\frac{f_{i} r_{s}}{\left(C_{1}+2\right) \delta_{s}} \\
F_{r s}=\frac{U_{s}}{\left(g^{\prime} \delta_{s}\right)^{1 / 2}}
\end{gathered} \mid
$$

である.

油層先端部の移動距離と油の流出時間との関係は,

$$
\begin{array}{r}
r_{*}(x)=r_{*}(x-1)+U_{n}(x-1) \Delta t_{*} \cdots \ldots . . \\
(x=1,2,3, \cdots)
\end{array}
$$

を逐次計算することにより得られる.ここに, $\Delta t_{*}=$ $\Delta t \cdot\left(U_{s} / r_{s}\right)$ である. 
なお, 油層の運動を表わす基礎方程式（8)，（9）に 特性微分方程式の理論を適用して得られた式 (22) は, Fay のモデルのように時間的な領域区分をすることな く, 重力・慣性力領域から重力・粘性力領域までの油層 の流動に対して適用できる.また, 式 (22) 中には流出 油量 $Q$ がパラメーターとして入っていないので, 原理 的には連続流出および瞬間流出のいずれの場合にも適用 できると考えられるが, そのためには連続流出, 瞬間流 出のそれぞれの場合について, 係数 $C_{1}$ および $C_{2}$ の值 が確定されなければならない，本研究では連続流出の場 合のみを対象とし, 次章で述べる連続流出の実験結果を 用いてこれらの係数を決定した.

\section{3. 解析結果および考察}

\section{(1) 抵抗係数 $\boldsymbol{f}_{i}$ について}

密度の異なる 2 種類の流体が, 内部に明確な密度界面 を作って共存しながら運動する場合，その界面での抵抗 は, 実用的な立場から式 (20) の形で表現されることが 多い ${ }^{17)}$. しかし, 油水界面の現象は, 界面を通して上下 層流体間の混合が生じないのが他の密度流現象とは大き く異なる点であり，その抵抗係数についての研究例は少 なく不明な部分が多い.ここではいくつかの研究結果を 引用しながら, 油水界面での抵抗係数について考察する.

首藤・大野 ${ }^{18)}$ は, 幅 $20 \mathrm{~cm}$, 深さ $30 \mathrm{~cm}$, 長さ $7 \mathrm{~m}$ の アクリル水槽の一端から石油を流出させ, その油層断面 形状の測定結果から油水界面の抵抗係数 $f_{i}$ を求め, $\Psi$ $=F_{i}^{2} \cdot R_{e}$ をパラメーターとして整理した． $F_{i}$ は油層の 密度フルード数で $F_{i}^{2}=U^{2} /\left\{\left(\Delta \rho / \rho_{w}\right) g \delta\right\}, R_{e}$ は油層のレ イノルズ数で， $\nu_{0}$ を油層の動粘性係数として $R_{e}=$ $U \delta / \nu_{0}$ で定義される. 首藤らの実験は $\Psi$ が 0.08 から 1 の範囲で行われ， $f_{i}$ の值は約 0.1 から 0.02 の間に分布 している.また， $\Psi$ が 0.2 以上では $f_{i}$ は減少する傾向 にある。

後藤 ${ }^{19)}$ は, 津波による油の挔がりに関する数値計算に おいて，首藤らの実験をもとに，

$f_{i}=f_{i}^{\prime} / R_{e}$

と仮定した。ここに $f_{i}^{\prime}$ は定数で, その值は, 埜口らに よる瞬間流出の実験デー- 夕と, $f_{i}^{\prime}$ を変化させた数值解 との比較結果から， $f_{i}^{\prime}=0.2$ が与えられた.

Lau \& Moir $^{20)}$ や Berry \& Rajaratnam ${ }^{21)}$ は，流れに 対して横断方向に設置されたオイルフェンスに補足され てその上流側に集積する油層と, その下層の水流との相 互作用についての研究を行った．彼らは，そのなかで, 油層の集積厚さを決定するのに必要な抵抗係数 $f_{i}$ を実 験的に求めている. Lau らは, 油と水の粘性係数の比 $\left(\mu_{0} / \mu_{w}\right)$ の異なる 3 種類の synthetic oil (No.1: $\mu_{0} / \mu_{w}$ $=7.14$, No. $3: \mu_{0} / \mu_{w}=66.04$, No. $4: \mu_{0} / \mu_{w}=348.09$ )
について, 油層断面形状の計算值が実験值と一致するよ うに抵抗係数を求め, OIL No. 1 で $f_{i} \fallingdotseq 0.006$, OIL No. 3 で $f_{i} \doteqdot 0.010$, OIL No. 4 で $f_{i} \fallingdotseq 0.012$ の值を得た. これらの実験では, 油層下部の水流のレイノルズ数はほ ぼ同じ条件に設定されているにもかかわらず，粘性の大 きい油ほど抵抗係数の值が大きくなっている. Berry ら は，粘性係数 $\mu_{0}=22.75 \mathrm{cP}$ の CWO base oil を用いて 油水界面付近の流速分布の測定結果から抵抗係数を計算 し, $f_{i} \fallingdotseq 0.008 〜 0.013$ を得た. 両者の得た値はほぼ同 じオーダーとなっている.

以上の研究結果から考えて, 式 (20) 中の抵抗係数は 油層のレイノルズ数の関数と考えるのが妥当であろう。 しかし, 現状ではその普遍的な関数形を確定するには データが不十分である. Fig. 2 は，次節で述べる湾口か らの油の連続流出の実験で, 湾内（湾口から奥へ 0.25 $\mathrm{m}$ の位置）湾口，および湾口から沖へ $2 \mathrm{~m}$ の位置の三 点で, 油膜厚さ測定装置により, 油層厚さの時間変化の ようすを測定した例 ${ }^{22}$ である。使用した油は，A重油と B 重油の 2 種類である. 図中の数字は湾口を原点とした 測点の位置を示している. 図によれば，連続流出時の油 層先端部では，瞬間流出の実験で流出直後にみられる内 部波の現象は観察されず, 最初から平滑なスリック状に ゆるやかに拡がっている. したがって, 本研究で扱って いる連続流出の実験の範囲では抵抗係数は一定とし, Lau \& Moir によって得られた実験值を抵抗係数として 用いることとする.

(2) 係数 $C_{1}, C_{2}$ について

式（16）および式（17）を用いて連続の式（8）を変 形すると

$\frac{\partial \delta}{\partial t}=-\left(C_{1}+C_{2}+1\right) \frac{U_{f} \delta_{f}}{r_{f}}$
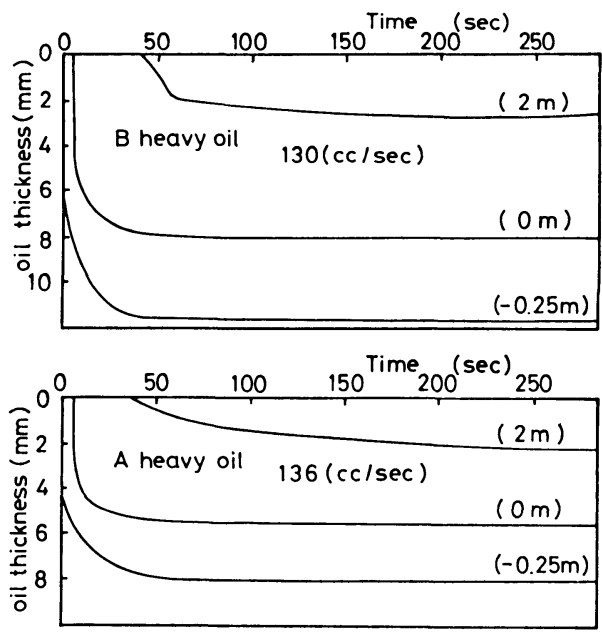

Fig. 2 Change of the thickness of continuously spilled oil from the mouth of the outlet. 
が得られる．油層先端がある点 $r=r_{\boldsymbol{s}}$ に達し，そこを 通過した直後においては，その点で観察すると式 (26) 左辺の $\partial \delta / \partial t$ は正の値を取るので

$$
C_{1}+C_{2}<-1 \cdots
$$

の条件が得られる. また, 油層先端部の厚みは時間の経 過とともに減少していくので， $d \delta_{f} / d r_{f}$ は常に負または 0 の値をとる.したがって，式（18）より，

$$
C_{1} \geqq-1
$$

の条件が得られる. また, Fig.1からもわかるように油

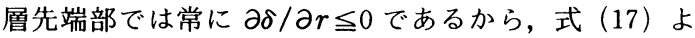
り

$$
C_{2} \leqq 0 \cdot
$$

の条件が得られる.

平野・羽田野 ${ }^{23)}$ は, 傾斜密度流先端部の流動機構の実 験において, 流下する密度流先端部に向けて後方から常 に塩水が流れ込んでいる，いわゆるプリュームの場合に は先端部付近の速度勾配 $\partial U / \partial r$ は負となり, 後方か らの塩水の流れ込みがないサーマルの場合には $\partial U / \partial r$ は正の值を取ることを示した。ここで扱っている油の拡 がりについても類似の現象が生じていると考えられ，流 出源から常に油が供給されている連続流出の場合は先端 部付近の速度勾配 $\partial U / \partial r$ は負の值を取る。したがっ て, 式 (16) より, 連続流出の場合

$$
C_{1}<0
$$

の条件が得られる.

式 (27)，(28)，(29）および（30）から，連続流出の 場合に係数 $C_{1}, C_{2}$ のとり得る值の範囲は, Fig. 3 の斜 線の部分で表わされる.

\section{（3）解析結果と実験值との比較}

2. で述べた理論を検証するため，小湾口から湾外の 水面へ連続的に油を流出させた場合の実験結果を用い て, 実験值と理論值との比較を行った。実験は, 幅 12 $\mathrm{m} \times 12 \mathrm{~m}$, 水深 $30 \mathrm{~cm}$ の平面水槽を用いて行い, 水槽の 一辺の中央に幅 $30 \mathrm{~cm}$, 奥行 $50 \mathrm{~cm}$ の小湾を作り, そこ から一定量の油を連続的に流出させて, 湾外での油の拡 がりを $16 \mathrm{~mm}$ カメラで写真撮影した ${ }^{24)}$.

Fig. 4 は, B重油 $4.4 \mathrm{l} / \mathrm{min}$ を流出させた場合の拡が

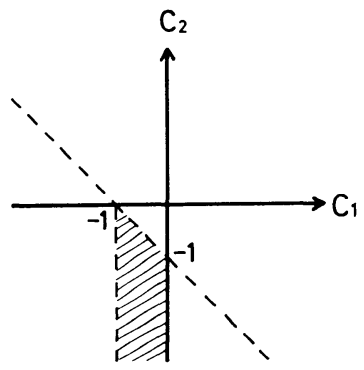

Fig. 3 Limits of the value of the coefficients $C_{1}$ and $C_{2}$.
りの一例を示している. 図中の数字は, 油が湾口から流 出し始めたときを $t=0 \mathrm{~s}$ とした経過時間である. 流出 油は，湾口を中心として半円状に拡がっていくが，湾口 付近では側壁の摩擦の影響で横方向への拡がりが抑えら れ，完全な軸対称の拡がりとはならない。ここでは，拡 がりの半径として, 側壁の影響が最も小さいと考えられ る，湾口から側壁に直角に沖に向かって油層先端までの 距離 $r_{f}$ をとり，それを拡がりの半径として理論値と比 較した。また，油層先端の速度 $U_{f}$ の実験值は， $r_{f}$ の測 定值をもとに, $U_{f}=d r_{f} / d t$ として求めた.

本実験で使用した油は，A重油およびB重油の 2 種類 で，一部の実験には水槽水温より約 $10^{\circ} \mathrm{C}$ 加熱した B重 油を使用しているが，その粘性はほぼA重油の粘性に等 しい. A 重油の粘性はLau らの使用した OIL No.1の 粘性にほぼ等しく，B重油の粘性はOIL No.3の粘性 にほぼ等しい.したがって, 式 (22) により油層先端速 度 $U_{n}$ を計算する場合には，実験に使用した油が $\mathrm{A}$ 重油 の場合については抵抗係数 $f_{i}$ は 0.006 を, B 重油の場 合には 0.01 を与えた。

連続流出の場合の係数 $C_{1}, C_{2}$ のとり得る值の領域は, Fig. 3 で示されるが，それぞれの值を理論的に決定する には至っていない。したがってここでは，次のような方 法で $C_{1}, C_{2}$ の值を決定した. ある 1 つの実験ケースに ついて，まず，それと同じ初期条件のもとに，式 (24) から各時刻での油層の拡がり $r_{* c}$ を求め, その值と実 験で得られた各時刻の油層の拡がり $r_{* e}$ との差の標準 偏差 $\sigma$ を求める。このとき, 計算に用いる $C_{1}$ と $C_{2}$ の 値は, Fig. 3 で許される領域内での適当な組合せを与え る. 次に, $C_{1}$ と $C_{2}$ の值を変えて同じ計算過程を繰り 返して, $r_{* c}$ と $r_{* e}$ の差の標準偏差值が最も小さくな るように， $C_{1} ， C_{2}$ の值を決定する.なお，解析上の初 期条件としては, 油が湾口から流出し始めた時刻を $t=$ $0 \mathrm{~s}$ として, 湾口から流出開始直後の第 1 回の形状測定 時の $r$ および $U$ を $r_{s}, U_{s}$ として与え, さらに $t=0$ か

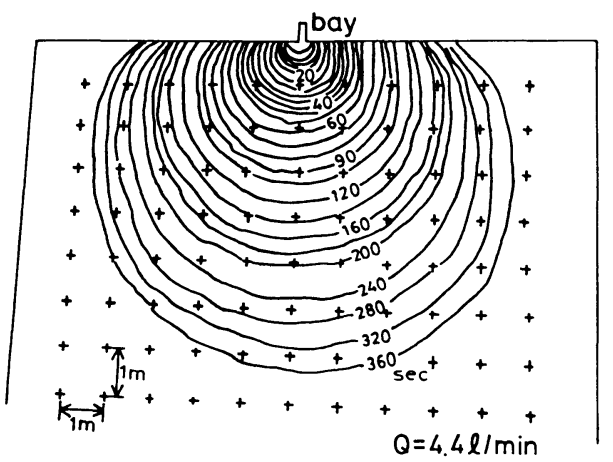

Fig. 4 Typical spreading pattern of continuously spilled oil from the mouth of the outlet. 


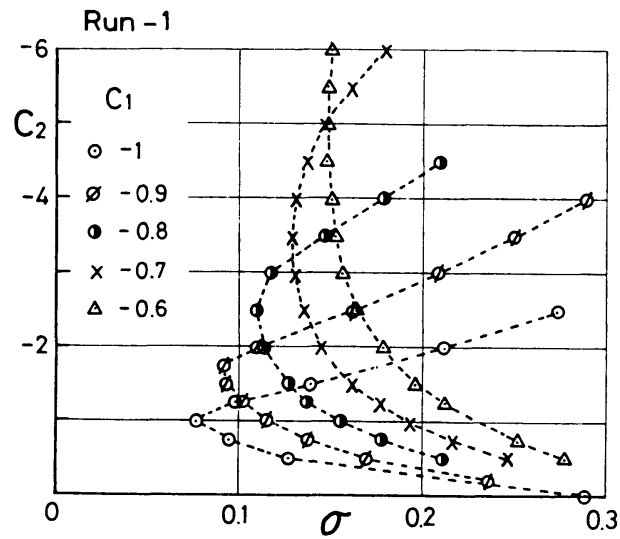

Fig. 5 Standard deviations of residual between $r_{* e}$ and $r_{* c}$ (Run-1: heated B-heavy oil).

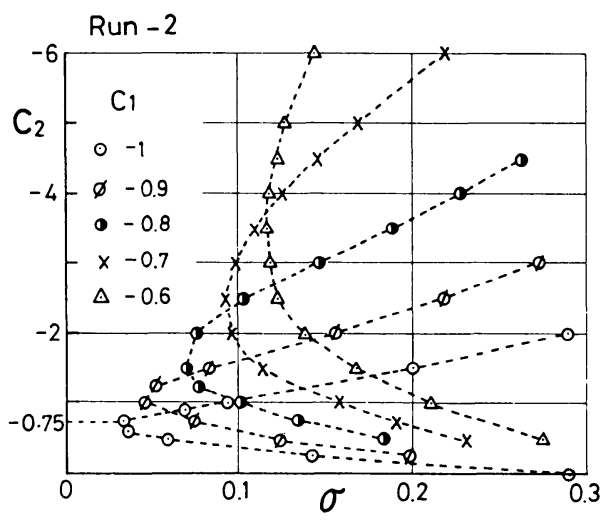

Fig. 6 Standard deviations of residual between $r_{* e}$ and $r_{* c}$ (Run-2: B-heavy oil)

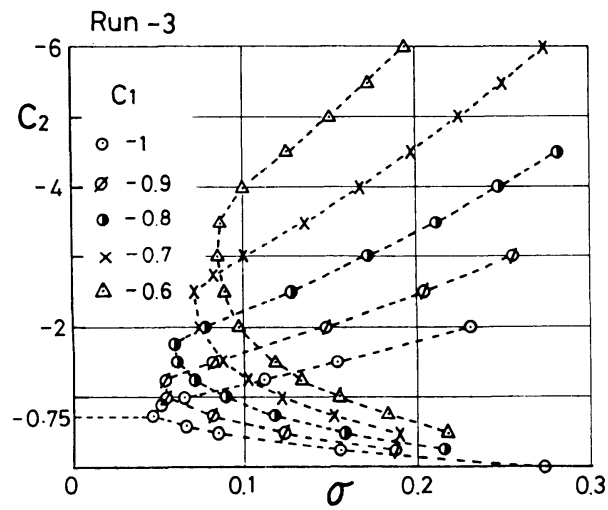

Fig. 7 Standard deviations of residual between $r_{* e}$ and $r_{* c}$ (Run-3 : A-heavy oil).

ら $t_{s}$ までに流出した油量から流出半径 $r_{s}$ の仮想円の油 層厚さを求め, それを $\delta_{s}$ と仮定した. Fig. 5 に, Run-1 の実験ケースについて求めた $\sigma$ の変化の様子を
示す. 図は, 縦軸に係数 $C_{2}$ をとり $C_{1}$ をパラメーター として図化している，図によれば，Run-1 で実験值と 計算值の差の標準偏差が最も小さくなる $C_{1}$ と $C_{2}$ の組 合せは, $C_{1}=-1, C_{2}=-1$ の場合であった. 同様の計 算を他の $2 つ の$ 実験ケース Run-2, Run-3についても 行った. その結果をFig. 6, 7 に示す.この 2 つの実験 ケースでは, いずれの場合も $\sigma$ の值が最小となる $C_{1}$ と $C_{2}$ の組合せは, $C_{1}=-1, C_{2}=-0.75$ であった. 以上 の結果から， $C_{1}$ の值は-1， $C_{2}$ の值としてはー0.75な いし -1 程度と考えられる. Run-2, 3 の值を採用して， $C_{1}=-1, C_{2}=-0.75$ とすると, 式 $(22)$ は

$$
\begin{aligned}
U_{n}^{2}= & \exp \left\{K\left(1-r_{*}\right)\right\}+\frac{1.50}{F_{r s}^{2}} \exp \left(-K r_{*}\right) \\
& \times \int_{1}^{r_{*}} u^{-1} \cdot \exp (K u) d u \ldots \ldots \ldots \ldots \ldots \ldots \ldots \ldots
\end{aligned}
$$

\section{と表わされる.}

Fig. 8(a), (b), Fig. 9(a), (b), および Fig. 10(a), (b) は, 3つの実験ケースについて, 式 (31) による $U_{n}$ お よび $r_{*}$ の計算值と実験值の比較を行った結果を示して いる. 図において, 横軸の $t_{*}$ は $t \cdot\left(U_{s} / r_{s}\right)$ を表わし, また図中の実線は計算値を, 黒丸印は実験値を示してい る.計算値は実験值によく一致しているといえよう。な お, $C_{1}=-1$ とすると, 式 (19) ふら $\delta_{s} / \delta_{s}=1$ が得ら れる.これに式 (17) をあわせて考えると, 連続流出で $C_{1}=-1$ の場合は, 油層先端には薄いくさび状の形状が 一定の部分があり, その部分を追跡して油層の拡がりを

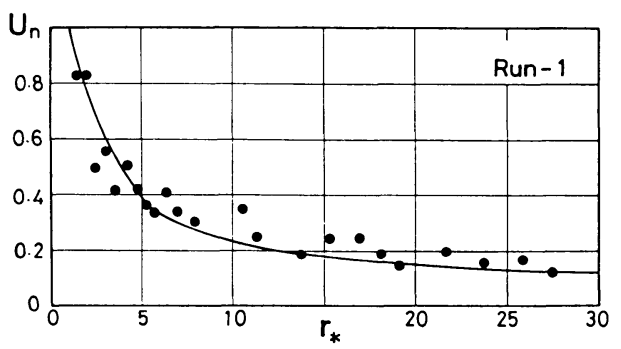

Fig. 8(a) Comparison between the calculated and measured values of $U_{n}$ (Run-1: heated B-heavy oil, $f_{i}=$ $0.006)$.

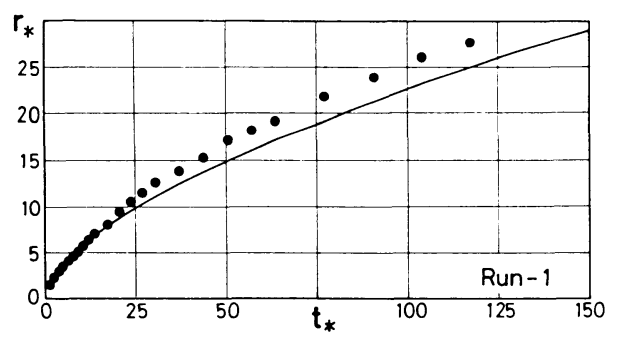

Fig. 8(b) Comparison between the calculated and measured values of $r_{*}$ (Run-1: heated B-heavy oil, $f_{i}=$ $0.006)$. 


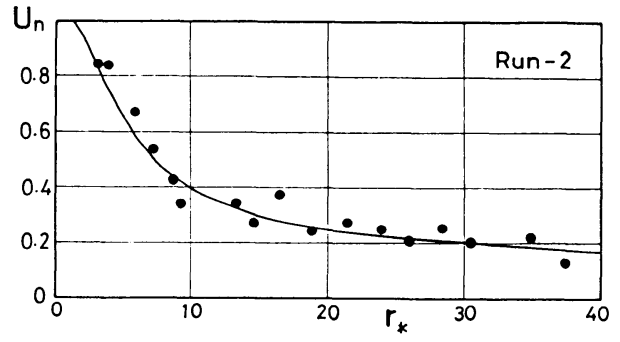

Fig. 9(a) Comparison between the calculated and measured values of $U_{n}$ (Run-2: B-heavy oil, $f_{i}=0.010$ ).

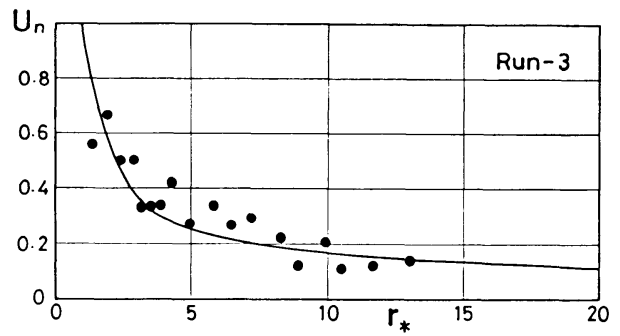

Fig. 10(a) Comparison between the calculated and measured values of $U_{n}$ (Run-3: A-heavy oil, $f_{i}=0.006$ ).
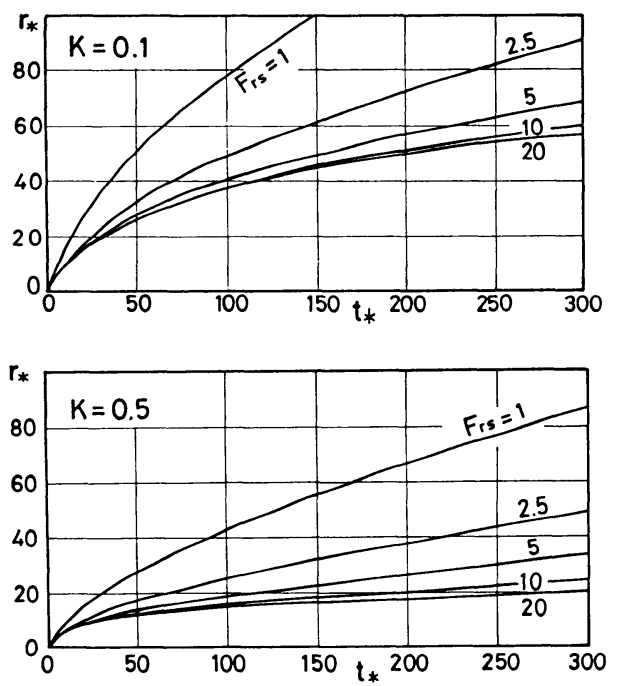

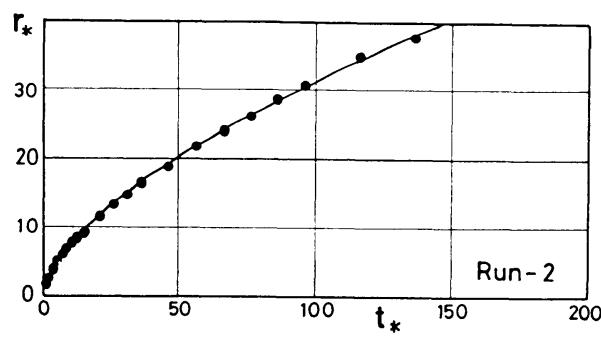

Fig. 9(b) Comparison between the calculated and measured values of $r_{*}$ (Run-2: B-heavy oil, $\left.f_{i}=0.010\right)$.

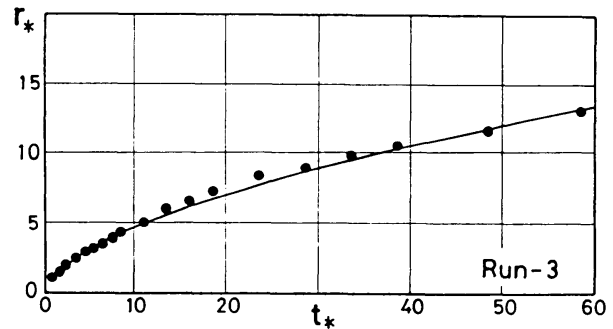

Fig. 10(b) Comparison between the calculated and measured values of $r_{*}$ (Run-3: A-heavy oil, $f_{i}=0.006$ ).
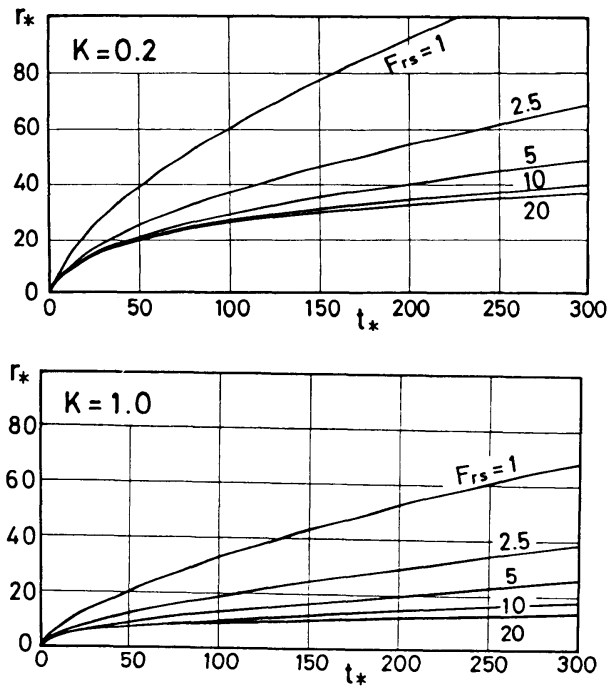

Fig. 11 Change of $r_{*}$ versus $K$ and $F_{r s}$.

求めていることになる.この仮定は, 比較的小量の油が 一定量で連続的に流出する今回の実験のような場合に は, ほぼ妥当な仮定と考えられるが, 種々の実験条件に 対し本モデルの適合性を高めるためには, 油層先端部の 形状の変化に関するデータを蓄積して, 係数 $C_{1}, C_{2}$ の 精度を向上させることが不可欠であろう。

Fig. 11 には， $F_{r s}$ および $K$ をパラメーターとして式 (31) および式 (24) から求めた $r_{*}$ および $t_{*}$ の関係
が示されている．図によれば，Kが一定の場合には $F_{r s}$ が大きくなるほど $r_{*}$ の傾きはゆるやかになり， $F_{r s}$ が 一定の場合には $K$ が大きくなるほど $r_{*}$ の傾きはゆる やかになっている.

\section{4. むすび}

本研究は, 静水面上に流出して軸対称的に拡がってい く油層について, 油層先端流速の変化, および油の流出 
後の経過時間と油層先端の拡がり大きさの関係を解析的 に求めたもので，その主な内容を要約すると以下のとお りである.

（1）油層の運動方程式および連続の式から, 特性微 分方程式を作ってそれを解き, 油層先端の流速変化を規 定する式を導いた。

（2）ここで得られた油層先端の流速変化，および油 層の拡がり大きさと流出時間の関係を表わす理論式は, 重力・慣性力領域から重力・粘性力領域にかけての油の 拡がりに適用できる．ここでは湾口から連続流出する油 の拡がりの実験データに基づいて，理論式の検証が行わ れた。

（３）連続流出の場合の油水界面での抵抗係数の值 は，Lau \& Moir の実験を参考にして，A重油の場合に は $f_{i}=0.006$, B 重油の場合には $f_{i}=0.01$ の值を用いた。

(4) 理論式の中に含まれる係数 $C_{1}, C_{2}$ の取り得る 值の領域はFig. 3 で示される.さらにその值は, 実験デ一 夕をもとに，実験值と計算値の差の標準偏差が最小にな るように決定され， $C_{1}=-1, C_{2}=-0.75$ が与えられた. これらの値を用いた連続流出の場合の計算値は, 実験値 によく一致することが確認された。なお，ここで得られ た係数 $C_{1}, C_{2}$ の值は連続流出の場合についての結果で あり，瞬間流出の場合には異なる值をとるものと考えら れる。それについては，さらに実験等に基づいた詳細な 検討が必要である.

\section{参 考 文 献}

1) 徳島県：三菱石油流出油事故対策報告書，1976 年.

2）田尻宗昭：油濁の海，日本評論社，1981 年.

3）環境庁水質保全局・(社) 瀬戸内海環境保全協会：瀬戸内 海の環境保全（資料集，昭和 60 年)，pp. 83.

4) 環境庁編 - 大蔵省印刷局発行: 昭和 61 年版環境白書, pp. 206 208.

5）資源エネルギー庁監修：1985 年資源エネルギー年鑑, pp. 203 204，通産資料調査会, 1985 年.

6) 前揭 5), pp. 383 -340.

7) 津田 覚 編: 瀬戸内海の油污染, pp. 89 120, 大日本 図書, 1976 年

8) Fay, J. A. : The spread of oil slicks on a calm sea, Oil on the Sea, Prenum Press, pp. 53 63, 1969.
9) Hoult, D. P. : Oil spreading on the sea, Annual Review of Fluid Mechanics, Vol.4, pp. 341 368, 1972.

10) Fannelop, T. K. and Waldman, G. D. : The dynamics of oil slicks-or "Creeping Crude", AIAA 9th Aero-space Sciences Meeting, No.71-14, January 25-27, 1971.

11) Fannelop, T. K. and Waldman, G. D. : Dynamics of oil slicks, AIAA Journal, Vol.10, No.4, pp. 506 510, 1972.

12) Buckmaster, J. : Viscous-gravity spreading of an oil slick, Journal of Fluid Mechanics, Vol.59, part 3, pp. 481 491, 1973.

13) Abbott, M.B. : On the spreading of one fluid over another, La Houille Blanche, No. 5, pp. 622 628, No. 6, pp. $827 \sim 846,1961$.

14）平野宗夫・羽田野袈装義：密度流先端部の流動特性につ いて,土木学会論文報告集,第 314 号, pp. 67 73, 1981 年.

15）平野宗夫・羽田野袈裟義：漸拡水路における密度流先端 部の挙動，土木学会論文報告集，第 322 号，pp. $47 \sim 54$, 1983 年.

16）たとえば, 犬井鉄郎：偏微分方程式とその応用, pp. 43 $\sim 48$, コロナ社, 1957 年.

17）土木学会編：水理公式集一昭和 60 年度版一, pp. 59 , 1985 年.

18）首藤伸夫・大野 操：石油の拡がりの実験, 第 24 回海岸 工学講演会論文集, pp. 509 513，1977 年.

19）後藤智明：津波による油の拡がりに関する数値計算, 土 木学会論文集，第 357 号，II-3，pp. 217 223，1985 年.

20) Iau, Y.L. and Moir, J. : Booms used for oil slick control, Journal of the Environmental Engineering Division, ASCE, Vol.105, No. EE2, 1979.

21) Berry, B.A. and Rajaratnam, N. : Oil slicks in ice covered rivers, Journal of the Hydraulic Engineering Division, ASCE, Vol.111, No. 3, March, 1985.

22）埜口英昭・山崎宗広：海面上に連続流出する油の挔がり， 第 26 回水理講演会論文集, pp. $569 \sim 575,1982$ 年.

23) Hirano, M. and Hadano, K. : On motion of turbidity current head (Part 3), 4th Congress-Asian and Pacific Division IAHR, Chanmai, Thailand, September, 1984.

24）埜口英昭・山崎宗広・橋本英資：静かな海面上に流出し た油の拡がりについて，中国工業技術試験所報告，第 12 号, pp. 17 40, 1980 年.

25）前掲 24）

（1987.10.28 - 受付 